\title{
Assessment of the LitToral Macrophyte Community in Jackson Lake, Grand Teton National Park, Wyoming
}

\author{
Carol A. Brewer \\ DEPARTMENT OF BOTANY — UNIVERSITY OF WYOMING \\ LARAMIE
}

\section{$\downarrow \quad$ INTRODUCTION}

Beginning in 1978, the water level of Jackson Lake, Grand Teton National Park, Wyoming, was lowered first from $2064.5 \mathrm{~m}$ (normal pool) to somewhere between 2060 - $2061 \mathrm{~m}$, and then in 1985 to $2057 \mathrm{~m}$. The purpose of these drawdowns was to facilitate repair and modification of the Jackson Lake dam. In 1989, repair was completed and the reservoir was allowed to fill back to the normal pool elevation of $2065 \mathrm{~m}$. Because of impacts to the littoral habitat in Jackson Lake caused by restoration of the dam at the Snake River outlet, the status of the aquatic plant community was assessed in August, 1989 and 1990. Previous investigations conducted in 1983 (prior to reconstruction) and 1985 (immediately following drawdown to $2055 \mathrm{~m}$ ) served as a baseline for comparisons. this report summarizes findings from the 1989 and 1990 studies on impacts to the littoral macrophyte community caused by the repair-related drawdowns. To evaluate the current status of the plant community in Jackson Lake, the following objectives were addressed during August, 1990:
1. Re-examine sites sampled in 1989;

2. Examine sites planted during the summers of 1989 and 1990 by the Bureau of Reclamation.

\section{Summary of Lake Conditions IN 1990}

\section{Photic ZoNe}

In general, the bottom limit of the photic zone was approximately the same during August 1990 as it was in 1989 and the past for most locations in the lake (Table 1). The bottom limit of the photic zone was still less than 2.5 meters in shallow water in both the northern part of the lake and in the Hermitage/Donoho Island areas. Low transparency values are attributed to increased suspended sediments in shallow areas due to high water movement during heavy August storms. Along steeper shores the photic zone was 19 meters. 
Table 1.Secchi disk transparency data and approximate bottom limit of the photic zone during the summer of 1968 by Hayden, and during the summers of 1983, 1984, and 1989 by Brewer. Site locations are illustrated in Figure 2. Values are in meters. The range for the bottom limit of the photic zone around the lake each year is estimated in the last row.

\begin{tabular}{|c|c|c|c|c|c|}
\hline \multirow[b]{2}{*}{ Site } & & \multicolumn{4}{|c|}{ SECCHI TRANSPARENCY VALUE (meters } \\
\hline & $\begin{array}{c}\text { August } \\
1990\end{array}$ & $\begin{array}{c}\text { August } \\
1989\end{array}$ & $\begin{array}{l}\text { July } \\
1984\end{array}$ & $\begin{array}{l}\text { July } \\
1983\end{array}$ & $\begin{array}{c}\text { August } \\
1968\end{array}$ \\
\hline Lizard Creek & 0.8 & 0.8 & & 1.8 & \\
\hline Wilcox Point & 1.5 & & & & \\
\hline NW of Arizona Island & 1.5 & 1.4 & & 1.1 & \\
\hline North Sargent's Bay & 2.5 & & & & \\
\hline UW-NPS Center & 3.5 & 2.9 & 2.9 & 3.5 & \\
\hline Half Moon Bay & 2.9 & & & & \\
\hline NE of Elk Island & 5.6 & & 4.5 & 3.0 & \\
\hline E of Waterfalls Canyon & 6.0 & 3.8 & & 4.2 & 6.0 \\
\hline S of Pilgrim Creek & 2.1 & 1.5 & & & \\
\hline W of Donoho Island & 6.0 & & & & \\
\hline South Landing Bay & 5.5 & 5.0 & 4.3 & 5.1 & \\
\hline Deadman's Point & 6.5 & 4.1 & 4.8 & 5.0 & 6.0 \\
\hline Bottom Limit of & 2.4- & $2.4-$ & 8.7- & $3.0-$ & $10.0-$ \\
\hline Photic Zone & 19.5 & 15.0 & 14.4 & 18.0 & 18.0 \\
\hline
\end{tabular}

\section{LAKe Bed SEDIMENTS}

Sediment composition is much the same as described in 1986. The film of fine silts which covered all sediments at the study sites in 1989 seems to have settled and is not easily mobilized by disturbance.

\section{Plant Community Composition}

In 1990, thirteen species were found rooted in Jackson Lake (Table 2). This value is up from eight species in 1989. Still species richness was considerably lower than in 1983/1984 when 22 species were reported. Two macrophyte source areas were found in the lake; one is in North Sargent's Bay and the other is in the Hermitage area. One new species, Limosela aquatica, was recorded for the first time in
Jackson Lake this summer. It is a small, amphibious plant commonly called mudwort.

\section{Plant Community Distribution}

Evaluation of historical transects in 1990 revealed extremely low plant density in the photic zone. In fact density was below detection limits for the Daubenmire canopy coverage method used in the past. On exposed shorelines, the littoral habitat is still essentially devoid of aquatic vegetation. On most of the shallow marshy lake bed, remnant terrestrial grasses, forbs, and willows are decaying. Blooms of a filamentous green algae (Spirogyra sp.), are associated with the decaying vegetation. At Wilcox Bay, near Arizona Island, in the borrow area, North Sargent's Bay, and at the outlet near Lizard Creek, the algae blooms were often quite prominent. Development of planted beds of 
Table 2. Names of families and species collected from Jackson Lake in 1968 by Hayden, reported by Brewer in 1986, and collected by Brewer in 1989. + indicates present, - indicates not reported, and ? indicates that the species may have been present but positive identification was not possible based on the plant material collected.

Family and

Species

1968

Years reported in collections 1986

1989

Alismataces

Sagittaria cuneata Shel.

Callitrichaceae

Callitriche sp.

Ceratophyllaceae

Ceratophyllum demersum L.

Characeae

Chara sp.

Nitella sp.-

Cyperaceae

Eleocharis acicularis (L.)R.\&S.

Haloragaceae Myriophyllum exalbescens Fern. Myriophyllum spicatum $\mathrm{L}$.

Hippuridaceae Hippuris vulgaris $\mathrm{L}$.

Hydrocharitaceae Elodea canadensis Michx. Elodea nuttallii (Planch)St.John

Polygonaceae Polygonum amphibium L.

Potamogetonaceae Potamogeton alpinus Balb. Potamogeton filiformis Pers. Potamogeton foliosus Raf. Potamogeton pectinatus $\mathrm{L}$. Potamogeton pusillus L. Potamogeton richardsonii (A.Benn)Rydberg Potamogeton sp.

Ranunculaceae Ranunculus aquatilis $\mathrm{L}$. Ranunculus reptans $\mathrm{L}$.

Scrophulariaceae Limosella aquatica

Sparganiaceae Sparganium sp.

Zannichelliaceae Zannichellia palustris $\mathrm{L}$.

Total species reported

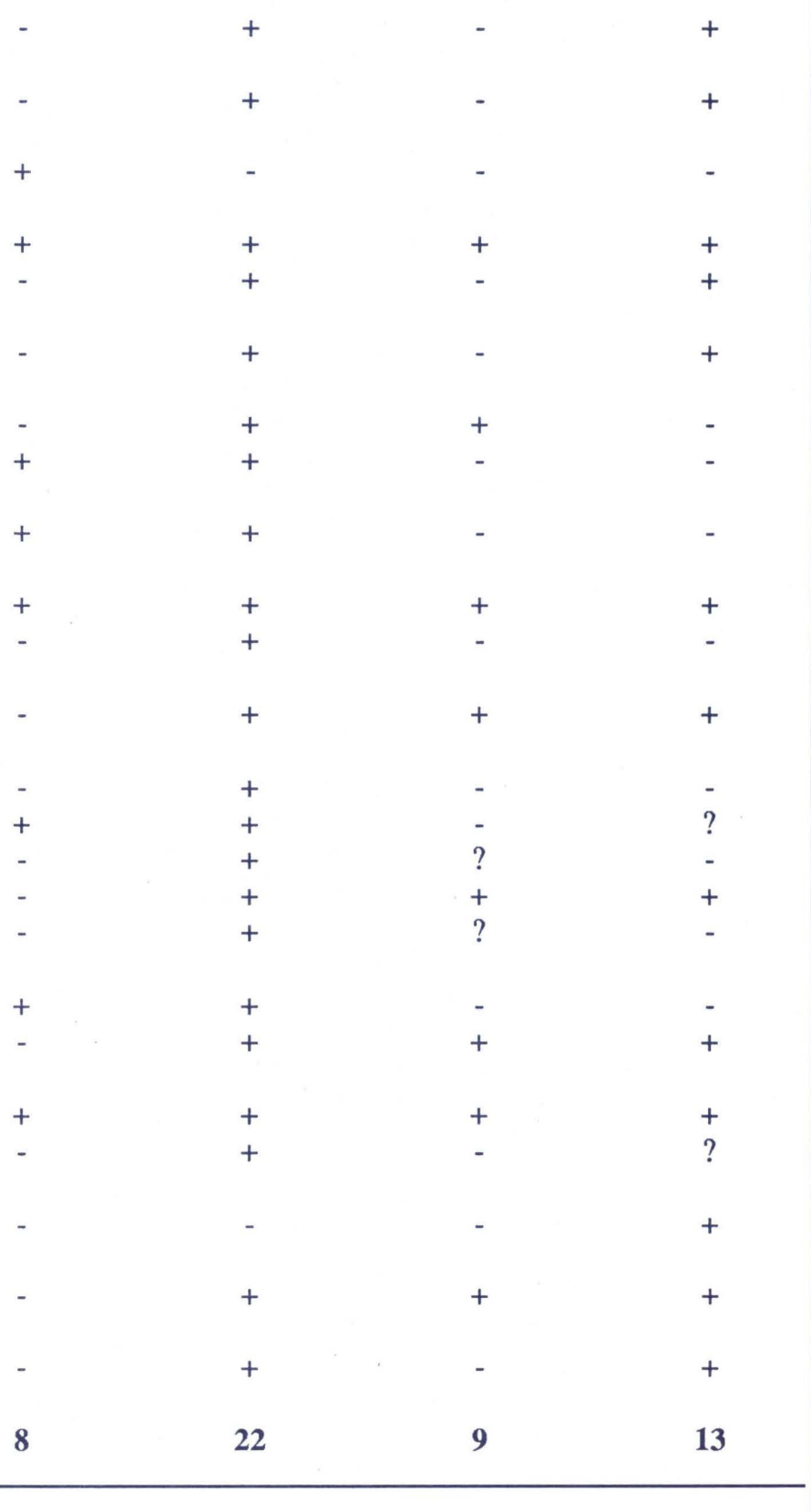


Potamogeton pectinatus in the Hermitage area, near the outlet of Lizard Creek, and in Half Moon and North Sargent's Bay is encouraging. Natural revegetation is occurring near Arizona Island.

Habitat for other organisms that rely on aquatic plants is nearly nonexistent along exposed shores at this time. Cover for trout fry, minnows and sculpin is still very low except in North Sargent's Bay, Hermitage, and between Arizona Island and the shore.

\section{RATE OF REVEGETATION}

During 1991, it may finally be possible to compare the rate of natural revegetation with the rate of revegetation the planted area of North Sargent's Bay. Material planted by the BOR in early summer 1990 was not relocated while diving. But, material planted in August 1990 was relocated by diving. Because there was still essentially no natural revegetation on historical transects, it will hopefully be possible to compare any natural recovery in 1991 with the transect in North Sargent's Bay which was planted in August 1990. The newly planted transects are clearly identified and should be very easy to relocate.

\section{REVEGETATION AND MONITORING RECOMMENDATIONS}

The northern marsh area (an arc from Arizona Island to the northern most part of the lake and then south to Wilcox Point) was planted in 1990 with Elodea canadensis and Potamogeton pectinatus. Unfortunately, there was an extensive bloom of Spirogyra sp. and planted material may not have survived. Continued revegetation efforts in these areas will likely benefit wildlife. Stabilizing the macrophyte community will continue to be instrumental for reducing turbidity as particulate material settles out in plant beds. These planted areas are normally in shallow water; so it is important that the lake level not be drawn down so that beds desiccate and die.
In 1989, I recommended two measures of recovery which should be evaluated: species richness (number of species present in each habitat and/or the lake as a whole) and cover of macrophytes on the lake bottom. Species richness increased in 1990 over 1989. I still think it is important to establish a target for species richness for key habitats in Jackson Lake, e.g., the northern marsh area and the Hermitage area. Hopefully, targets for diversity and cover, by key species used by wildlife, can be agreed upon by the agencies involved prior to the 1991 field season. Such criteria can be used to determine if the current planting strategy produced adequate recovery. Planting both Potamogeton pectinatus and Elodea canadensis has certainly contributed to reestablishing the macrophyte community.

In August 1991, the sites evaluated in 1989 and 1990 should be remeasured by diving to determine if species richness and plant cover have increased. Again, any cover by aquatic macrophytes along historical transects greater than zero will show some level of recovery. Species richness in each habitat type and in the entire lake can be easily compared to 1989 and 1990 data.

\section{ACKNOWLEDGEMENTS}

This study was funded by the Bureau of Reclamation with coordination through the Wyoming Game and Fish Department and the U.S. Fish and Wildlife Service. The field assistance of Tom Thompson (Wyoming Game and Fish Department) and of the staff at the UW-NPS Research Station are greatfully acknowledged. 